analyze the best practice and systematize the thinking and research into the problem. In the meantime the management world is laid under obligation to these institutions for their pioneering spirit and their placing themselves in a position to make a contribution to what many now regard as the most important phase of management.

In the growth of employment management societies and in the closer connection between them and management training courses, both employer and employe may find valuable assistance in overcoming waste and in developing new possibilities of coöperation.

\title{
THE WORK OF THE EMPLOYMENT DEPARTMENT OF DENNISON MANUFACTURING COMPANY, FRAMINGHAM, MASSACHUSETTS
}

\section{By Philip J. Reilly,}

Employment Manager.

The employment department of the Dennison Manufacturing Company was established on its present basis on January 1, 1914.

This department was expected to improve the human relationships and to reduce the labor turnover of the industry (a) by making a careful study of the requirements of its various occupations; (b) by engaging persons who could best meet those requirements and see that they were adequately instructed; (c) by transferring to other occupations any promising employes who were unadapted to the first job; and (d) by heedfully noting the reasons given by employes for quitting, so that steps could be taken to eradicate any common cause that was making employes dissatisfied and causing them to leave.

Although studies of other phases of employment work were of assistance, it was mainly through the careful study given to the foregoing divisions of placement work that the employment department was able in a large degree, to accomplish the expected results.

In the Dennison factory about 10 per cent of the force of 2,200 employes are engaged in the so-called skilled trades. This small group represents machinists, electricians, carpenters, compositors, 
electrotypers and pressmen. The balance of the force represents those who were unskilled when they were engaged. Many employes in this group, however, are on jobs which require just as long an apprenticeship and whose requirements are just as exacting as the "skilled" trades. Of this larger group about 60 per cent are females and 40 per cent are males, and those in this group follow some 150 different occupations, many of which will be found only in this industry. The chief problem in selection has been to obtain satisfactory non-skilled employes for these jobs.

The employment department prepared and has on file written specifications covering each of the jobs for which non-skilled labor can be hired. These specifications were prepared with the coöperation of the head of each factory department. They contain all the information that each foreman's experience could yield that was of value in selecting employes for every occupation in his department.

These job specifications also contain a brief description of the duties of the job; the schooling or the sort of experience that is desirable in an employe; the posture of the employe, that is, whether employe will be sitting or standing, stooping or walking; the preferable age, weight and height of an employe; whether employe should be right or left-handed; the starting wage; the time taken by an average employe to earn an advance in wages; the probable maximum earnings of the position, and whether the job is steady or seasonal.

The information revealed by these job analyses led to a grading of jobs according to the usual maximum earnings of each. The positions having the lowest earnings were designated as " $\mathrm{C}$ " positions; those with a little higher wage range were designated as " $\mathrm{B}$ " positions, and the most desirable places of all with the highest wage range were designated as "A" positions. By grading positions according to the wage range of each group, the employment department was able to fill vacancies in grade $\mathrm{A}$ by transfering an employe from a grade $B$ position, or if none was available by transferring an employe from a grade $\mathrm{C}$ position. This policy of promotion from within opened new channels to advancement and has resulted in the organization obtaining a higher type of employe for the grade $\mathrm{C}$ jobs, because even these have the "prospects for advancement" which are needed to sustain the interest of the new employe who is ambitious. 
Requisitions for new employes are sent on a printed form to the employment department. These are usually sent at least several days before the employe is needed. For this reason the industry is able to select applicants from its waiting list who are working elsewhere but who can be released from their employment by giving adecuate notice of their intention to change. Applicants are asked to give this notice to their employers before they are engaged by the Dennison factory. This reminds them of an obligation that they should discharge and this custom has resulted in their invariably notifying, several days in advance, their department foreman in our business of their intention of quitting.

In selecting from our waiting list an applicant for a given position, we review the information which the interview and application blank have revealed. If it is decided that an applicant can meet the requirements of a certain job, we then give consideration to any influences external to the industry which may cause the applicant to leave. We ascertain why he seeks employment with us; where he regularly lives; what his earnings were in his former position, and why he left it. In most cases we can get in addition other information from persons in our employ, the names of whom are usually given by applicants as references.

When an applicant is engaged, the requirements of the position he is about to fill are clearly outlined to him. For this purpose the job analysis is followed so that every point which should interest the new employe will be covered. On the subject of wages, care is used to underestimate slightly the probable earnings so that the new employe is not misled by a too favorable outline of the job. $\mathrm{He}$ is informed concerning the hours of employment, of the advantages that come from steady work and of the aims of our organization.

When an employe reports for work he is given a copy of our Bool of Information and Instruction, on the cover of which is printed his name and his department number. This book explains the industrial service activities of our company. This includes an explanation of the Dennison suggestion system, under which employes may obtain cash awards; the advantages of membership in the mutual relief associations; the operation of the factory savings and loan fund; the circulating library, and other company activities which offer many advantages to the employes. This book also 
urges employes to avoid accidents and explains the provisions of the Massachusetts workmen's compensation law, under which all employes are insured.

The new employe is then sent to the training department where he is taught the special knowledge necessary to equip him for his position. He is shown the most approved and best methods for doing the work, as determined by the time study work of the efficiency department. He is taught such correlated knowledge as the principles of machine constructions, how the materials he uses are made, and how to care for them. When the employe is familiar with the work he is to do, and is able to earn a specified wage, he is transferred to the actual manufacturing department.

The purpose of this training department is twofold. Its first function is to fit the new employe for his particular work in the plant. It relieves the foremen of the trouble and expense of breaking in new help. It is supposed to do the work more quickly and more thoroughly than the foremen have time to accomplish. Its second function is to pass on the vocational aptitudes of the new employe. In a plant with so many different classes of work, it is impracticable to predetermine the exact aptitudes that the applicants for the work may have. Psychological tests may do this in the future, but for the present actual experience at the job is the only safe guide.

The employment department follows up the new employe during the first three months. If he is succeeding on the job his wages will be advanced at an opportune time. Advances in wages are recommended in writing by department heads after each monthly examination of their pay roll. The productive records of the employe are referred to when such recommendations are made.

These recommendations are sent to the employment department and are checked against the records of each employe which are on file there. In addition to the name, age, rate of wages and length of service of the employe, this record shows the number of suggestions and the number of errors made by him.

Usually the pay recommendations are approved by the employment department and sent to the works manager for final approval. If a recommendation is questioned by the employment department, however, the reasons for not approving it are given to the works manager, who will not approve the recommendation unless some 
additional reasons for approving it are given by the department head.

If an employe has not succeeded in the position in which he was placed, the employment department then takes up the matter of moving him to another department or of dismissing him entirely from the service. Complete information about an employe's shortcomings is obtained from the department head. Based on this information and upon an interview with the employe, a decision with respect to disposing of the employe is made.

The matter -of transferring employes from one department to another required very careful study when the employment department was organized. Department heads in the past had passed on to one another many incompetent employes, and most of them looked with suspicion upon any new move to give employes a second trial at another job.

The policy of transferring employes from one department to another to promote them as well as to give another chance to the promising employes who failed to "make good" on their first jobs, however, has changed the attitude of the department heads towards transferred employes, and the industry now saves many employes to its service who would otherwise be lost. The reasons for transferring 219 employes in 1915 were: Advancing employes to better positions in other departments, 40 per cent; changing employes who asked to be placed on another line of work, 4 per cent; changing employes who were not adapted to the first job in which they were placed, 18 per cent; changing employes to other work when seasonal work for which they were engaged was finished, 29 per cent; changing employes to other positions for miscellaneous reasons, 9 per cent.

Transfers of labor are recorded in the employment department only when an employe is taken from one department and placed in another under the supervision of a different department head. Employes may be advanced from one position to another in the same department without that fact being recorded in the employment department, or they may be changed from one kind of work to another within the same department. If this change is occasioned by the fact that the employe has not made progress on the first job, the employment department is notified.

The Dennison company has made a careful study of how to regulate the manufacture of seasonal goods. It has persuaded its 
customers to place orders very early in the year for holiday goods. It now makes large runs of staple articles at periods of the year in which many of its facilities were formerly idle. It has developed an extensive line of specialities for St. Valentine's Day; St. Patrick's Day; Easter and patriotic holidays which come during the first part of the year, and for which it employs the same machinery as was formerly used only for Christmas specialties. By dovetailing these activities it has kept its trained hands steadily employed, and has greatly reduced labor turnover and labor costs.

When an employe decides to leave the company, notice of this decision is usually given a week in advance. The employment manager interviews the employe and records the reason on a printed "Leaving Slip." An effort is always made to get the true reason. Instances where an employe is dissatisfied either with his wages, his work or the conditions under which his work is performed, are of especial concern to the employment department. If any employe has suffered an injustice steps are taken to prevent a repetition of the complaint. Because the employment department has been interested to record the reason given by each departing employe for leaving its service, and to tabulate this information at intervals, it has been able to discover a number of common causes of dissatisfaction which resulted in large numbers of employes leaving.

This information resulted in remedial recommendations being made which, when adopted, almost immediately resulted in stopping the exodus of dissatisfied employes. The number of employes lost by this company in 1913 because they were dissatisfied for one reason or another, probably was no greater than the number lost for similar reasons by other industries, because the average labor turnover of this industry was no worse than the average labor turnover of other industries in its class. However, by reason of the steps taken by the company to remove causes that tended to make employes dissatisfied, it was able to reduce these cases to such an extent that the total number recorded in 1915 represents only $17 \frac{1}{2}$ per cent of the total number who left in 1913 because they were dissatisfied either with their wage or their work. This appears to be a remarkable showing when it is remembered that there are always in every industry types of restive employes, small in numbers to be sure, who seem to be dissatisfied with any job no matter how advanta- 
geous appears the opportunity for advancement it offers or how fair its wage may be.

When it is necessary to discharge an employe, the department head notifies the employment department of his intention and states the reason for such a step. After considering all of the circumstances, sometimes another trial is given to the employe, either on the same job or on another job. In the event of an employe being discharged the department head could not prevent his being placed in another department if it was decided to re-engage the employe later. The works manager only is empowered to exclude absolutely an employe from the organization, and this is done only in very rare cases.

The effectiveness of the work of an employment department is usually judged by the extent to which it has succeeded in reducing the changes in the personnel of its industry. Needless labor turnover is an expense that burdens many industries. A conservative estimate is that the expense of replacing an experienced hand averages $\$ 50$ in this industry. On this estimate the savings represented by the reduction which has been effected in the labor turnover since the employment department was established on its present basis approximates $\$ 25,000$. The figures of labor turnover for this industry, which represents not only employes who quit work but also all who were laid off or dismissed for any causes, were: $1911-68$ per cent; $1912-61$ per cent; $1913-52$ per cent; 1914-37 per cent; $1915-28$ per cent.

Although this marked reduction in the changes of the working force is in itself a sufficient justification for establishing and maintaining a central employment department, the Dennison company feels that other values in addition have accrued from the deeper study it has given to its employment problems.

It has been worth a lot to learn from its own experience, for example, how vital to the contentment and efficiency of a working force it is to have as foremen men who, in addition to good judgment, have a manner that invites the friendship as well as the respect of employes.

In the departments headed by men of this sort, an employe was rarely distressed because a reasonable request had not been readily granted or because the foreman's attitude in handling a matter requiring tact as well as firmness had been such as to invite 
friction. Foremen who were unfeeling and arbitrary in handling matters unimportant in themselves, had caused many valuable employes to leave the industry, despite the fact that their earnings were very high and that their work was very interesting.

It has been well worth while also for the industry to have maintained through its employment department a point of contact with the employes that has resulted in their feeling free to express themselves with reference to the adjustments that they thought should be made in their work or in their wages, whenever a foreman seemed to them to be insensible to their deserts.

It is because the employment department has been in a position to render such effective coöperation to heads of departments and to extend such encouragement to those employes who may have found themselves temporarily out of harmony with their work environment, that its work in this business has been so well worth while.

\title{
THE EMPLOYMENT WORK OF THE CURTIS PUBLISHING COMPANY
}

\author{
By Robert C. Clothier,
}

Employment Manager, The Curtis Publishing Company.

The raising of the standard of efficiency of the working force, individually and as a whole, in order that the purchasing power of the wage-dollar may be increased-this, as we interpret it, is the broad function of the employment department. It is not my intention to give you a finished speech tonight, for two reasons: first, because of a certain constitutional inability to do so; and second, because, although we feel that we are making progress in our efforts at human engineering, yet we have a long road to go before we even approach the end; so my paper tonight will be devoted merely to telling you about what we have succeeded in doing and in some measure what our plans are for the future.

The phrase "employment department" would be a misnomer if

${ }^{1}$ Paper read before Philadelphia Association for the Diseussion of Employment Problems, April, 1916. 